EXEMPLARIa Classica

Journal of Classical Philology

17, 2013, pp. 45-61

ISSN 1699-3225

\title{
A JUMBLED MANUSCRIPT OF CICERO'S SPEECHES: MADRID BIBL. NAC. 10119
}

\author{
Michael D. ReEve \\ Pembroke College, Cambridge \\ mdr1000@cam.ac.uk
}

\begin{abstract}
SuMMARY
A full account is given of the unusual disorder in the text of Cicero's speeches on ff. 124-239 of Madrid Bibl. Nac. 10119. The origin of the manuscript is then discussed together with its closest relatives and the history of its text.
\end{abstract}

KEYWORDS

Cicero, speeches, manuscript, bifolia, disorder, Petrarch

\section{RESUMEN}

Se ofrece una descripción exhaustiva del inusual desorden del texto de los discursos de Cicerón de los ff. 124-239 de Madrid Bibl. Nac. 10119 y se estudia el origen de este manuscrito junto con otros testimonios muy cercanos y la historia del texto.

Palabras Clave

Cicerón, discursos, manuscrito, bifolia, desorden, Petrarca

Fecha de recepción: 10/04/2013

Fecha de aceptación y versión final: 11/06/2013

Madrid Bibl. Nac. 10119 is a 15th-century parchment manuscript of 248 leaves that contains in 24 quires of five bifolia, ff. 1-240, most of Cicero's speeches. Though it has been described in print at least five times ${ }^{1}$, none of the descriptions reveals the tiresome fact, which I pointed out in 1984, that from f. $124 \mathrm{r}$ to $\mathrm{f}$. $239 \mathrm{v}$ no fewer than 67 units of text are jumbled because of misplaced leaves in its exemplar or a remoter ancestor ${ }^{2}$. I added that ff. 202

${ }^{1}$ The fullest description remains M. Schiff's in La bibliothèque du Marquis de Santillane, Paris 1905, 56-8. See also É. Pellegrin, "Manuscrits des auteurs classiques latins de Madrid et du Chapitre de Tolède”, Bull. d'Inf. de l'I. R. H. T. 2, 1953, 7-24, at 15; S. Rizzo, Catalogo dei codici della Pro Cluentio ciceroniana, Genoa 1983, 72-3 no. 51; L. Rubio Fernández, Catálogo de los manuscritos clásicos latinos existentes en España, Madrid 1984, 375-7 no. 456; Inventario general de manuscritos de la Biblioteca Nacional XIV, Madrid 2000, 346.

2 "The manuscripts of the Pro Cluentio", $C R$ n. s. 34, 1984, 42. I saw the manuscript on the spot in May 1983 but later ordered a microfilm, which I thank the Biblioteca Nacional 
and 209 of the manuscript itself have changed places; they form the second bifolium of a quire, and it was inserted the wrong way round. In 1983 for my own purposes I had listed the contents in order and reconstructed in a paper model the quires of the exemplar or remoter ancestor. Since then, I have not had occasion to use the jumbled section, but other scholars may find it easier to use if I publish my results. I take the opportunity of considering where and when the manuscript was produced and where it belongs in the textual tradition of the speeches.

THE DISORDER IN MADRID NAC. 10119

The exemplar or remoter ancestor contained 24 speeches and the Commentariolum petitionis. The original order began as follows:

Pro lege Manilia, Pro Milone, Pro Plancio, Pro Sulla, Pro Archia, Pro Marcello, Pro Ligario, Pro rege Deiotaro, Pro Cluentio, Pro Quinctio, Pro Flacco, Post reditum ad Quirites, Post reditum in senatu.

Of these thirteen speeches, all known to Petrarch and widely attested in this order after his death ${ }^{3}$, the first twelve were not affected by the misplacement, but it affected the last and then the Commentariolum and the other eleven, where the original order was this:

Commentariolum, Pridie(spurious), Post reditum ad Quirites (another version), De domo, In Vatinium, Pro Caelio, Pro Roscio Amerino, Pro Murena, Pro Balbo, De haruspicum responsis, De provinciis consularibus, Pro Sestio.

The misplacement befell the last seven quires, which I shall call h-o because they were almost certainly preceded by seven others. Quire $\mathrm{n}$ had ten leaves, the rest twelve; they made a total of 82 . The misplacement had the following results in the ancestor (on the left) and Madrid Nac. 10119 (on the right) ${ }^{4}$ :

for supplying; in December 2012 an anonymous informant at the Biblioteca Nacional kindly drew my attention to the digital version of the whole manuscript now available on line in the Biblioteca Digital Hispánica. On the number of jumbled units see below.

${ }^{3}$ I say more at the end here about the witnesses to these speeches.

${ }^{4}$ The second figure in the references is the line of the O. C. T., where Pro Roscio Amerino, Pro Murena, and Pro Caelio, appear in volume I of Orationes, 1905, the other genuine speeches in volume V, 1911, and the Commentariolum in volume III of Epistulae, 1958. For Pridie I use the edition of Orelli-Baiter-Halm, volume II 2, Zürich 1856, 1412-20; there is a Mondadori edition by M. De Marco, 1991, but I doubt if it is widely available. 
h: f. 1 ?? - Sen. 18.25 consules

f. 75 Har. 53.25 nomina - 60.9 paucis

f. 3 Sen. 30.2 egi (ei ms.) - Comm. 3.4 cura

f. 74 Har. 45.5 id -53.25 certa

f. 4 Comm. 3.4 et saepe - 18.12 etiam

ff. 6-7 Comm. 33.13 quemque - Prid. 4.14 ut his

f. 9 Prid. 14.3 -tionem - 24.16 immortales

f. 79 Prov. 24.29 est igitur - 33.14 acerrimis

f. 10 Prid. 24.16 qui excellenti - Quir. 4.20 caritatis

f. 78 Prov. 15.12 alter - 24.29 num

f. 12 Quir. 16.12 uni-??

j: f. 13 ?? - Dom. 11.6 consilii

f. 5 Comm. 18.12 si suffragandi - 33.13 optimum

f. 52 Mur. 22.14 de nocte - 29.15 actionibus

f. 26 Dom. 134.18 manu - 144.2 quocirca te

f. 14 Dom. 11.6 capere - 20.1 defenderet

ff. 30-31 Cael. 1.6 non posset - 21.12 alieno

f. 23 Dom. 103.20 disturbare - 113.27 comportarent

f. 35 Cael. 49.7 oculorum - 57.22 redundet

f. 57 Mur. 61.3 et egregia - 69.17 gratuitam non

f. 8 Prid. 4.14 nisi - 14.3 conspira-

f. 24 Dom. 114.27 venio - ??

k: f. 25 ?? - Dom. 134.18 tremebunda (teme- ms.)

f. 15 Dom. 20.1 bello - 30.10 calamitatem

f. 27 Dom. 144.2 Capitoline - Vat. 7.7 denique

f. 17 Dom. 40.19 omnis - 50.24 tetigit

f. 29 Vat. 23.29 arma - Cael. 1.6 stare

ff. 18-19 Dom. 50.24 digito - 70.6 rettulit

f. 32 Cael. 21.12 dolori - 31.1 sollicitavit

f. 20 Dom. 70.7 iudicavit-82.23 modo in

f. 34 Cael. 39.20 vitam - 49.7 flagrantia

f. 22 Dom. 93.11 quam de -103.20 vestris

f. 36 Cael. 57.22 id igitur - ??

1: f. 37 ?? - Rosc. 9.6 conqueri neque satis

f. 73 Har. 38.13 non fuit -45.5 excluserat

f. 38 Rosc. 9.6 libere - 22.17 familia

f. 16 Dom. 30.10 etiam - 40.19 tua

f. 2 Sen. 18.25 vestra -30.2 universis

ff. 76-77 Har. 60.9 bonorum - Prov. 15.12 quorum

f. 11 Quir. 4.20 quid voluptatis - 16.12 unus

f. 21 Dom. 82.23 civium (cum ms.) - 93.10 gloriari

f. 47 Rosc. 123.30 diligenter - 137.11 non

f. 80 Prov. 33.14 nationibus - 41.7 assentiebar
?? - 124r 5

$124 \mathrm{r} 5-125 \mathrm{v} 2$

$125 \mathrm{v} 2-127 \mathrm{r} 13$

127r 13 - 128v 13

128v 13 - 130r 24

130r $24-133$ v 5

133v $5-134$ v 19

$134 \mathrm{v} 19$ - 136r 6

136r 6 - 137r 25

137r 25 - 138v 15

$138 \mathrm{v} 15$ - ??

?? - 141v 12

141v 12 - 143r 24

143r $24-144 v 18$

144v 18 - 146r 23

146r $23-147$ v 16

$147 \mathrm{v} 17-150 \mathrm{v} 14$

150v 15 - 152r 23

152r $23-153$ v 23

153v 23 - 155r 27

155r 28 - 156v 12

$156 \mathrm{v} 12$ - ??

?? - 159v 20

159v $20-161$ r 8

161r 8 - 162r 35

162r $36-163 \mathrm{v} 21$

$163 \mathrm{v} 21-165 \mathrm{r} 8$

165 r $8-167$ v 28

167 v 28 - 169r 26

169r $26-170 v 18$

170v 18 - 172r 1

172r 1 - 173r 33

173 r 33 - ??

?? - 176r 11

176r 11 - 177r 29

177r 29 - 178v 24

178v 24 - 180r 12

180r $12-181$ v 6

181v 7 - 184r 14

184r 14 - 185r ult.

185r ult. - 187 r 4

187r 4 - 188v 14

188v 14 - 190r 6 
f. 48 Rosc. 137.11 debeo - ??

190r 7 - ??

m: f. 49 ?? - Mur. 5.14 eam quam

?? - 193r 16

f. 41 Rosc. 49.28 accusatorio - 60.9 et citro

$193 \mathrm{r} 16-194 \mathrm{v} 20$

f. 62 Balb. 17.24 nostrae - 25.14 alienigenarum

194 v 20 - 195v 34

f. 50 Mur. 5.14 mihimet - 13.13 quibus

195v $34-197$ r 29

f. 63 Balb. 25.14 nos hominum - 33.11 potest

197r $30-198 \mathrm{v} 13$

ff. 54-55 Mur. 34.16 non minus - 51.26 quia timebant

198v $13-201 \mathrm{v} 9$

f. 68 Har. 2.3 quam est -10.19 maximis

201v $9-202$ v ult. $^{5}$

f. 59 Mur. 78.2 arbitraretur - 88.23 vertet

202 v ult. $-204 \mathrm{v} 14$

f. 69 Har. 10.19 prope iam (propria ms.) - 16.27 sit mihi

$204 \mathrm{v} 14-205 \mathrm{v} 35$

f. 44 Rosc. 84.2 tecum - 96.17 possum

$205 \mathrm{v} 35-207 \mathrm{v} 5$

f. 60 Mur. 88.23 domum (demum ms.) ne- ??

n: f. 61 ?? - Balb. 17.23 civitatis

$207 \mathrm{v} 5$ - ??

f. 51 Mur. 13.13 praeterea - 22.14 vigilas tu

?? - 210r 35

f. 64 Balb. 33.12 nisi- 41.8 fingi

210r 35 - 211v 34

f. 53 Mur. 29.15 anteponenda - 34.16 operam (opiam ms.)

211 v $34-213$ r 28

ff. 65-66 Balb. 41.8 orationem - 59.24 iustam

213 r $28-214$ v 27

f. 56 Mur. 51.27 cum erupit - 61.3 divina et

$214 \mathrm{v} 27-217 \mathrm{v} 19$

f. 67 Balb. 59.24 et debitam - Har. 2.3 vulnerari

$217 \mathrm{v} 19-219 \mathrm{r} 23$

f. 58 Mur. 69.18 modo dignitati - 78.1 apprehensurum

219r 23 - 220v 18

f. 70 Har. 16.28 data - ??

220v 18 - 222r 26

222r 26 - ??

o: f. 71 ?? - Har. 30.20 optimo

f. 28 Vat. 7.7 ipsius - 23.29 Sullana

?? - 225r 5

f. 72 Har. 30.20 per te -38.13 dolori

225r 5 - 226v 12

f. 40 Rosc. 34.25 consideremus -49.27 artificio

226v $12-228 \mathrm{r} 6$

$228 \mathrm{r} 6-229 \mathrm{v} 10$

f. 39 Rosc. 22.17 qui neminem - 34.25 expositam

229v $10-231 \mathrm{r} 11$

ff. 42-43 Rosc. 60.9 et citro -84.2 reperio

231r $11-234 r 5$

f. 46 Rosc. 111.10 turpe - 123.30 facio neque

$234 \mathrm{r} 5-235 \mathrm{v} 6$

f. 45 Rosc. 96.17 inquit - 111.10 non minus

$235 \mathrm{v} 6-237 \mathrm{r} 5$

f. 81 Prov. 41.8 tamen - Sest. 1.6 si quem

237 r 5 - 238r 25

f. 33 Cael. 31.1 quos potuit - 39.20 hanc tu

$238 \mathrm{r} 25-239 \mathrm{v} 13$

f. 82 Sest. 1.6 bonum - ??

$239 \mathrm{v} 13$ - ??

In the ancestor, thanks doubtless to catchwords, the outer bifolia of each quire stayed in the right place. Furthermore, the inner bifolia all remained inner bifolia, even when they moved to another quire. When I was working out my reconstruction, Bruce Barker-Benfield suggested a convincing explanation: as sometimes happens ${ }^{6}$, the outer and inner bifolia were parchment but the rest paper, and whoever assembled the bifolia in their

${ }^{5}$ I mentioned above that ff. 202 and 209 have changed places. I treat them here as though they had not.

${ }^{6}$ See for instance S. Rizzo, Catalogo, 106, on Paris B. N. Lat. 7783. 
jumbled order recognized that any parchment one without a catchword belonged in the middle of a quire. If each inner bifolium and each pair of leaves where quires meet is counted as a unit of text, the 82 leaves contained 69 units of text. As it was not just the seven outer bifolia that kept their place - eight units, namely the first and last and the six where quires meet - but also, presumably by mere chance, ff. $3+10,27+34,29+32,54-55,65-66$, the misplaced units numbered 53 , but the effect was the jumbling of all but the first and last of the 69 or even, since there is no continuation to anchor the last, of all but the first. That is how I arrived at the figure of at least 67.

In the table I have indicated where each passage falls in Madrid Nac. 10119, but anyone hunting for a specific passage will probably be more grateful for the following table, drawn up by reference to the original order in the ancestor:

?? - Sen. 18.25 consules

Sen. 18.25 vestra - 30.2 universis

Sen. 30.2 egi (ei ms.) - Comm. 3.4 cura

Comm. 3.4 et saepe -18.12 etiam

Comm. 18.12 si suffragandi-33.13 optimum

Comm. 33.13 quemque - Prid. 4.14 ut his

Prid. 4.14 nisi - 14.3 conspira-

Prid. 14.3 -tionem - 24.14 immortales

Prid. 24.14 qui excellenti - Quir. 4.20 caritatis

Quir. 4.20 quid voluptatis - 16.12 unus

Quir. 16.12 uni-??

?? - Dom. 11.6 consilii

Dom. 11.6 capere - 20.1 defenderet

Dom. 20.1 bello - 30.10 calamitatem

Dom. 30.10 etiam - 40.19 tua

Dom. 40.19 omnia - 50.24 tetigit

Dom. 50.24 digito -70.6 rettulit

Dom. 70.6 iudicavit -82.23 modo in

Dom. 82.23 cum numero - 93.10 gloriari

Dom. 93.11 quam de -103.20 vestris

Dom. 103.20 disturbare - 113.27 comportarent

Dom. 114.27 venio - ??

?? - Dom. 134.18 tremebunda

Dom. 134.18 manu - 144.2 quocirca te

Dom. 144.2 Capitoline - Vat. 7.7 denique

Vat. 7.7 ipsius - 23.29 Sullana

Vat. 23.29 arma - Cael. 1.6 stare

Cael. 1.6 non posset - 21.12 alieno

Cael. 21.12 dolori - 31.1 sollicitavit
?? - $124 \mathrm{r} 5$

180r $12-181 \mathrm{v} 7$

$125 \mathrm{v} 2-127 \mathrm{r} 13$

$128 \mathrm{v} 13$ - 130r 24

$141 \mathrm{v} 12$ - 143r 24

130r $24-133 \mathrm{v} 5$

155r $28-156 \mathrm{v} 12$

$133 \mathrm{v} 5-134 \mathrm{v} 19$

136r 6 - 137r 25

184r 14 - 185r ult.

$138 \mathrm{v} 15$ - ??

?? - 141v 12

146r $23-147 \mathrm{v} 17$

159v 20 - 161r 8

178v 24 - 180r 12

163v $21-165$ r 8

165r $8-167 v 28$

169r $26-170 v 18$

185r ult. - 187 r 4

172r 1 - 173r 33

150v 15 - 152r 23

$156 \mathrm{v} 12$ - ??

?? - 159v 20

$144 \mathrm{v} 18$ - 146r 23

161r 8 - 162r 36

225r 5 - 226v 12

162r 36 - 163v 21

$147 \mathrm{v} 17-150 \mathrm{v} 15$

167v 28 - 169r 26 
Cael. 31.1 quos potuit - 39.20 hanc tu

Cael. 39.20 vitam - 49.7 flagrantia

Cael. 49.7 oculorum - 57.22 redundet

Cael. 57.22 id igitur - ??

?? - Rosc. 9.6 conqueri neque satis

Rosc. 9.6 libere - 22.17 familia

Rosc. 22.17 qui neminem - 34.25 expositam

Rosc. 34.25 consideremus -49.27 artificio

Rosc. 49.28 accusatorio - 60.10 et citro

Rosc. 60.9 et citro -84.2 reperio

Rosc. 84.2 tecum - 96.17 possum

Rosc. 96.17 inquit - 111.10 non minus

Rosc. 111.10 turpe - 123.30 facio neque

Rosc. 123.30 diligenter - 137.11 non

Rosc. 137.11 debeo - ??

?? - Mur. 5.14 eam quam

Mur. 5.14 mihimet - 13.13 quibus

Mur. 13.13 praeterea - 22.14 vigilas tu

Mur. 22.14 de nocte - 29.15 actionibus

Mur. 29.15 anteponenda -34.16 operam

Mur. 34.16 non minus - 51.26 quia timebant

Mur. 51.27 cum erupit - 61.3 divina et

Mur. 61.3 et egregia - 69.17 gratuitam non

Mur. 69.17 modo dignitati - 78.1 apprehensurum

Mur. 78.2 arbitraretur -88.23 vertet

Mur. 88.23 domumne - ??

?? - Balb. 17.23 civitatis

Balb. 17.24 nostrae - 25.14 alienigenarum

Balb. 25.14 nos hominum - 33.11 potest

Balb. 33.12 nisi-41.8 fingi

Balb. 41.8 orationem - 59.24 iustam

Balb. 59.24 et debitam - Har. 2.3 vulnerari

Har. 2.3 quam est -10.19 maximis

Har. 10.19 prope iam (propria ms.) - 16.27 sit mihi

Har. 16.28 data - ??

?? - Har. 30.20 optimo

Har. 30.20 per te -38.13 dolori

Har. 38.13 non fuit -45.5 excluserat

Har. 45.5 id - 53.25 certa

Har. 53.25 nomina - 60.9 paucis

Har. 60.9 bonorum - Prov. 15.12 quorum

Prov. 15.12 alter - 24.29 num

Prov. 24.29 est igitur - 33.14 acerrimis 238r $25-239 \mathrm{v} 13$

$170 \mathrm{v} 18$ - 172r 1

152r $23-153 \mathrm{v} 23$

173 r 33 - ??

?? - 176r 11

177r 29 - 178v 24

$229 \mathrm{v} 10-231 \mathrm{r} 11$

228r 6 - 229v 10

193r 16 - 194v 20

231r 11 - 234r 5

$205 \mathrm{v} 35-207 \mathrm{v} 5$

$235 \mathrm{v} 6$ - 237r 5

$234 \mathrm{r} 5-235 \mathrm{v} 6$

187r 4 - 188v 14

190r 7 - ??

?? - 193r 16

195v 34 - 197r 30

210r $35-211$ v 34

143r $24-144 v 18$

213r 28 - 214v 27

198v 13 - 201v 9

$217 \mathrm{v} 19$ - 219r 23

$153 \mathrm{v} 23-155 \mathrm{r} 28$

220v 18 - 222r 26

209v ult. - 204v 14

207v 5 - ??

?? - 210r 35

$194 \mathrm{v} 20-195 \mathrm{v} 34$

197r 30 - 198v 13

211v $34-213 r 28$

$214 \mathrm{v} 27-217 \mathrm{v} 19$

219r 23 - 220v 18

201v 9 - 209v ult.

204v $14-205 \mathrm{v} 35$

222r 26 - ??

?? - 225r 5

226v 12 - 228r 6

176r 11 - 177r 29

127r $13-128 \mathrm{v} 13$

$124 \mathrm{r} 5-125 \mathrm{v} 2$

181v 7 - 184r 14

137r 25 - 138v 15

$134 \mathrm{v} 19$ - 136r 6 
Prov. 33.14 nationibus - 41.7 assentiebar

Prov. 41.8 tamen - Sest. 1.6 si quem

Sest. 1.6 bonum - 14.19 quiescunt
$188 \mathrm{v} 14-190 \mathrm{r} 7$

237r 5 - 238r 25

$239 \mathrm{v} 13-240 \mathrm{v}$ ult.

This table makes it clearer than the other that Madrid Nac. 10119 breaks off early in Pro Sestio. It does so at the end of a quire, but unlike the previous quires this one has no catchword: only a set of concluding squiggles. As the last page is much longer than usual and the writing cramped, the scribe must have wanted to avoid embarking on a new quire for a few sentences. In that event, the rest of Pro Sestio must already have been missing from the ancestor, and it seems that the ancestor must have had the same word as Madrid Nac. 10119 at the end of its last quire, whether in the body of the text or as a catchword. At first sight, Sest. 1.6 bonum - 14.19 quiescunt is too long to have been accommodated in a single leaf, but B. L. Harl. 4927 (s. xii), from which it ultimately came, has many omissions in the passage. Nevertheless, it still looks too long, and I have not yet hit on a satisfactory explanation.

British Library Harl. 4927, Petrarch, and the teXt of Madrid NaC. 10119

Before continuing with Madrid Nac. 10119, I must say more about Harl. 4927. It includes a run of ten speeches that had travelled together since Antiquity: Pridie, Post reditum ad Quirites, Post reditum in senatu, De domo, In Vatinium, Pro Caelio, Pro Balbo, De haruspicum responsis, De provinciis consularibus, Pro Sestio. The most conspicuous peculiarities of its text are that Post reditum ad Quirites opens with 2 Quirites etsi and Pro Caelio ends with 70 commissa vobis. Most Italian manuscripts of the ten speeches owe them wholly or partly to it, but some of the ten also reached Italy from different sources in versions defective at other points ${ }^{7}$. Who in Italy first used Harl. 4927, and when, has not yet been established. Doubt has recently been cast on the view that Petrarch owned and annotated it $^{8}$, and certainly he is unlikely to have owned it, because in 2010 I identified

${ }^{7}$ On the transmission of Cicero's speeches see R. H. Rouse \& M. D. Reeve in L. D. Reynolds (ed.), Texts and transmission, Oxford 1983, 54-98, where 57-61 deal with the ten speeches in question. For other versions of In Vatinium and Pro Caelio that circulated in Italy see my article "Before and after Poggio: some manuscripts of Cicero's speeches", RFIC 112, 1984, 26684; for another of Pro Sestio, T. Maslowski's Teubner edition, Leipzig 1986, xviii; for another of Pro Balbo, my preface to his posthumous Teubner edition of De provinciis consularibus and Pro Balbo, Berlin \& New York 2007, vii, where I also refer to what I have written about another of De provinciis consularibus and De haruspicum responsis.

${ }^{8}$ M. Fiorilla, 'Marginalia' figurati nei codici di Petrarca, Florence 2005, 28-31; M. Berté "Petrarca, Salutati e le orazioni di Cicerone", in P. De Paolis (ed.), Manoscritti e lettori di Cicerone tra Medioevo e Umanesimo, Cassino 2012, 21-52, at 24-7. 
it as a manuscript described in papal inventories of about 1411 and 1423 from Peñíscola9. The papal manuscript 'fuit venditus Johanni Munionis', Juan Muñoz, an associate of the Aragonese pope Benedict XIII ${ }^{10}$. In addition, Harl. 4927 may also have been the manuscript that Jean de Montreuil in 1403-4 was trying to obtain from a friend in Avignon, which had belonged to Pierre d'Ameil, Galeotto Tarlati da Pietramala, and Nicola Brancacci; he described it in his letter as volumen quoddam operum quam multorum Ciceronis correctissimum, respectu tamen incorrectionis aliorum and in another letter, addressed to a dignitary in Paris, as volumen ... in quo libri morales Tullii pluresque orationes sue continentur ..., scriptum, quod aiunt, littera nec antiqua nimis nec nova et satis correctum, respectu tamen incorrectionis aliorum ${ }^{11}$. If the identification is right, then three owners are known before the papal library, which must have acquired it from the last of them, Nicola Brancacci $(\dagger 1412)$, a close associate of Benedict XIII ${ }^{12}$.

However the text of Harl. 4927 entered circulation, there are three respects in which Madrid Nac. 10119 stays closer to it than most Italian manuscripts. Despite putting after Pro Flacco a complete version of Post reditum ad Quirites taken from a different source ${ }^{13}$, it keeps (or restores)

${ }^{9}$ M. Faucon, La librairie des papes d'Avignon, Paris 1886-7, II, 132 no. 829; M. H. Jullien de Pommerol \& J. Monfrin, La bibliothèque pontificale à Avignon et à Peñíscola pendant le grand schisme d'Occident et sa dispersion, Rome 1991, II, 676 no. Pc 350. For other details see M. Berté, "Petrarca", 24-5.

10 M. H. Jullien de Pommerol \& J. Monfrin, La bibliothèque, loc. cit. and I, 422 no. 283. The identification reopens the question whether it later belonged to the Catalonian scholar Petrus Galesius, whose manuscripts, or some of them, were appropriated in 1593 or soon after by the earliest institution that has left a mark of ownership in it, namely the Jesuit college at Agen; see H. Omont, "La bibliothèque de Pedro Galés chez les Jésuites d'Agen", Journal des Savants n.s. 3, 1905, 380-84. Even if it did, though, he travelled so widely in Italy and worked for so long at Geneva and in the south of France that he need not have acquired it in Catalonia.

${ }^{11}$ E. Ornato, Jean Muret et ses amis Nicolas de Clamanges et Jean de Montreuil, Geneva 1969, 154-9. P. L. Schmidt, Die Überlieferung von Ciceros Schrift 'De legibus' in Mittelalter und Renaissance, Munich 1974, 432-3, identified the manuscript with Wolfenbüttel Gud. Lat. 2, but Ornato in a letter of 1981 to Richard Rouse objected that nec nova does not suit it, and Maslowski cited the objection in his edition of Pro Sestio (n. 7), xv; instead Ornato suggested identifying it with Harl. 4927. On Gud. Lat. 2 see now G. Mariani Canova, "Per i classici di Rolando da Piazzola: Nerio miniatore a Padova e il Cicerone gudiano", IMU 50, 2009, 345-52 with plates IV 1, VI; I shall discuss elsewhere its missing text of Post reditum in senatu.

${ }^{12}$ On Brancacci see the Dizionario biografico degli italiani 13, 1971, 793-6 (D. Girgensohn).

${ }^{13}$ In fact it is the composite version of Paris B. N. Lat. $7778\left(\mathrm{~s} . \mathrm{xiv}^{2}\right)$, where a corrector added the end of the speech after 23 verum etiam from Harl. 4927 or a descendant. See my Teubner edition of Pro Quinctio, Stuttgart \& Leipzig 1992, xi. I illustrated the hands in "Recovering annotations by Petrarch", in Il Petrarca latino e le origini dell'umanesimo= Quaderni petrarcheschi 9-10, 1992-93, 333-48, where the plate opposite 336 shows the comparable transition at Post reditum in senatu 7. 
the headless version, which at first glance appears to be a different speech ${ }^{14}$; it keeps In Vatinium after De domo, whereas many Italian manuscripts, among them early ones such as Vat. Barb. Lat. 142, Vat. Pal. Lat. 1476, and Vicenza Bertol. G 242 1, put it after Pro Balbo; and it keeps Pro Sestio after De provinciis consularibus, whereas many Italian manuscripts, among them the same early ones, put it after Pridie ${ }^{15}$. In fact the only change it makes in the Harleian speeches, as I shall call them, is to drop Post reditum in senatu, already taken from a different source. This fidelity to Harl. 4927 makes unlikely any connexion with perhaps the earliest Italian descendant of Harl. 4927, namely B. L. Add. 19586 (s. xiv/xv), which puts De haruspicum responsis at the end, after the Caesarians, Philippics, and Paradoxa. Four other manuscripts, though, have all the same speeches as Madrid Nac. 10119 from Pro lege Manilia to Pro Sestio except that they also drop the headless version of Post reditum ad Quirites; they are Cesena S. 19.2, Palermo Naz. IV G 7, Parma Palat. 59, and Vat. Reg. Lat. 1486. In Oxford Linc. Lat. 40 only Pro Archia is absent from the sequence (lost after f. 58, the end of a quire? $\left.{ }^{16}\right)$, and in Oxford Bodl. Canon. Class. Lat. 255 the earlier speeches of the sequence are lost before Post reditum ad Quirites 21.23 -rent laudi ${ }^{17}$.

${ }^{14}$ I have met it in 18 Italian manuscripts, but unlike Madrid Nac. 10119 most of them restore the true opening of the speech after 11 pertulerunt; so at least Copenhagen $\mathrm{Gl} . \mathrm{Kgl}$. S. $20024^{\circ}$ (which also has the complete version), Florence Laur. 48.18 and S. Croce $14 \mathrm{sin}$. 9, Florence Naz. II II 65, Oxford Ball. 248A, Paris B. N. Lat. 17154 (which also has the complete version), Pistoia A 32, Siena H XI 64, Vat. Ottob. Lat. 1991, Vat. Lat. 1746, most of which are Florentine. Paris B. N. Lat. 7778 and 17883 have in the margin at 2 Quirites etsi the note 'quidam libri habent hic principium (+ huius 17883 ) orationis et quod est supra non habent'. The scribe of Naples Naz. IV B 8 (s. xiv/xv), on which see L. Gualdo Rosa, Molto più preziosi dell'oro: codici di casa Barzizza alla Biblioteca Nazionale di Napoli, Naples 1996, 24-5 no. 4 with plates 17-18, copied out the headless version, but Gasparino Barzizza or someone close to him restored missing passages in the margin, among them the opening. Vat. Ottob. Lat. 1463 and Vicenza Bertol. G 2421 have the complete version twice. Two manuscripts that usually have a sophisticated text, Vatican Pal. Lat. 1480 and Munich Lat. 15734 , surprisingly have the headless version.

${ }^{15}$ Naples Naz. IV B 8 (n. 14) now begins with Post reditum ad Quirites but does not include Pro Sestio, which it must have put after Pridie in the missing section; and it too puts In Vatinium after Pro Balbo. Another early manuscript now lost, Dresden Dc 109, did the same, as I learnt in 1983 when the Sächsische Landesbibliothek supplied me with J. C. Götze's description, Die Merckwürdigkeiten der Königlichen Bibliotheck zu Dresden, Dresden 1743, I, 491.

${ }^{16}$ When I saw the manuscript about 30 years ago, I noted the quiring as $2-50^{10}$ (with a leaf cut out after f. 48), 51-58, 58 bis-307 ${ }^{10}$.

${ }^{17}$ S. Rizzo, Catalogo, 32 on Cesena S. 19.2, mentions that I drew her attention to the sequence attested by Madrid Nac. 10119 and these other six manuscripts. In M. D. Reeve, "The manuscripts", 42 on no. 9 (Cesena S. 19.2), I retracted part of what she reports on my authority about transpositions in Pro Sestio and In Pisonem; more on these below. Canon. Class. Lat. 255 treats Pro Caelio as Pro Marcello, a confusion also found in Palermo Naz. IV G 7 and Reg. Lat. 1486; but I have no further information about titles in the group except 
On the other hand, Madrid Nac. 10119 and the other six manuscripts interrupt the Harleian speeches after Pro Caelio by inserting Pro Roscio Amerino and Pro Murena, unknown in Italy till 1415, when the text of a manuscript found at Cluny began to circulate ${ }^{18}$. The Commentariolum too, it seems, began to circulate at much the same $\operatorname{time}^{19}$, and they put it before the Harleian speeches. After the Harleian speeches the other six manuscripts add speeches unknown in Italy till 1417, when Poggio found them in Germany: Cesena S. 19.2 adds In Pisonem, De lege agraria, Pro Rabirio Postumo, Pro Caecina, Pro Rabirio perduellionis reo, the rest In Pisonem, Pro Rabirio Postumo, Pro Rabirio perduellionis reo, Pro Caecina. As the jumbled ancestor of Madrid Nac. 10119 seems to have lost quires after Pro Sestio 14.19 quiescunt, it may well have lost some of Poggio's German speeches too.

The five manuscripts that end or once ended with Pro Caecina have In Pisonem 30.27 privatis - 68.24 audistis and 20.4 barbaro - 30.27 quae lex after Pro Sestio 108.2 contionem $^{20}$. The two passages are also missing from In Pisonem in Vienna 3122 and 3148, which I saw in 1983, but 3148 does not include Pro Sestio, and in $3122 \mathrm{I}$ did not check the text at 108.2. Written in 1461 by Jeronimus de Surim (or Gurim), 3122 ends with the same eleven speeches as the five manuscripts in question, from De domo to Pro Caecina ${ }^{21}$. Did the transpositions come about in the ancestor of Madrid Nac. 10119 before those that affected only Madrid Nac. 10119? No: I have checked the length of the passages, and it does not match the length of the passages misplaced in Madrid Nac. 10119.

that Canon. Class. Lat. 255 muddles other speeches too and Madrid Nac. 10119, though it bestows no title on any speech, does bestow an appropriate subscription on a few, among them Pro Caelio.

${ }^{18}$ Stephen Oakley will soon publish an article on the transmission of these two speeches, but meanwhile the fullest treatment of the lost Cluniacensis is Rizzo's, La tradizione manoscritta della Pro Cluentio di Cicerone, Genoa 1979, 49-82.

${ }^{19}$ See my edition of Pro Quinctio (n. 13), xxviii n. 28. L. Frati, "Indice dei codici latini conservati nella R. Biblioteca Universitaria di Bologna”, SIFC 16, 1908, 103-432, at 375 no. 867, assigns Bologna Univ. 1677 to s. xiv, but Comm. pet. is not in the same hand as Ovid's Ars amatoria, which antedates a jotting on f. 26v apparently made in 1299 or 1300 (“... millesimo ducentesimo indictione duodecima te $<\mathrm{m}>$ pore domini Bonifatii pape ottavi die septimo mensis Martii ..."), and the $M$ of the subscription DEO GRATIAS AMEN, which I take to be in the same hand and ink as the text of Comm. pet., has the Byzantine form attested in Italy from about 1410 to about 1460 .

${ }^{20}$ See note 17 above and my article "The familia Cusana of Cicero's speeches De lege agraria and In Pisonem", in C. Leonardi \& B. Munk Olsen (ed.), The classical tradition in the Middle Ages and the Renaissance, Spoleto 1995, 57-74, at 66-7.

${ }^{21}$ S. Rizzo, Catalogo, 173, omits Pro Rabirio perduellionis reo from her description. 
The TEXTS AT THE END OF MADRID NAC. 10119 AND THEIR BEARING ON ITS DATE

After the speeches of Cicero's Madrid Nac. 10119 has these four pieces:

ff. 241r-242v (untitled and undated): Sunt quos iuxta te stare rex Romane vides venerandus vicecamerarius illustris senator conservatores magnifici et magistratus urbis ceteri cum quibus populus Romanus ad salutandum te nos cives suos misit meque iussit apud te gaudium quod eis adventus tuus attulit detegere ..., addressed to the emperor Frederick III in March 1452 when he came to Rome for his coronation ${ }^{22}$;

ff. 243r-246r (untitled and undated): Si solus huic oneri ..., a speech addressed to Charles VII of France at Bourges on August 28th 1440 by a delegation from Eugenius IV, introduced by a preamble that names its members, reverendum patrem dominum episcopum Melden., spectabilem militem et comitem et utriusque iuris doctorem celeberrimum dominum Iohannem Franciscum de Capitibus Liste, et reverendum patrem magistrum Iohannem de Turrecremata sacre theologie professorem famosissimum et scolarum sacri palatii apostolici magistrum, et me humilem capellanum tuum; the first three were Pierre de Versailles, Gianfrancesco Capodilista from Venice, and Juan de Torquemada, and the speaker was Bartolomeo Zabarella, archbishop of Florence ${ }^{23}$;

f, 246v (untitled): Apparuit temporibus nostris ..., the Letter of Lentulus (a medieval invention), so called because the preamble Temporibus Octaviani Augusti Cesaris ..., found here and in many other humanistic manuscripts, names him as the author; he appears here not just as Lentulus but as P. Lentulus ${ }^{24}$;

${ }^{22}$ L. Bertalot, Initia humanistica latina, Tübingen 2004, II 2, no. 21971, who cites only this manuscript.

${ }^{23}$ L. Bertalot, Initia humanistica, no. 22697, who knows the speech only from Salzburg St Peter b VIII 15. On the convocation at Bourges see Monumenta conciliorum generalium seculi decimi quinti, Basel 1932, III, 504-12; N. Valois, Le pape et le concile (1418-1450), Paris 1909, II, 224-42. That Zabarella was chaplain to the king, or had been, I have not read in any modern work, but the sources name him as a member of the delegation, and it may be that the manuscript at Salzburg attributes the speech to him.

${ }^{24}$ E. von Dobschütz, Christusbilder: Untersuchungen zur christlichen Legende, Leipzig 1899, 308**-330**, listed dozens of manuscripts and several editions, edited the text, and discussed the origin and diffusion of the work; his list, which consists mainly of northern-European manuscripts, does not include Madrid Nac. 10119. On $327^{* * *}$ he mentions $P$. as a rarity. 
ff. 246v-248r (added in what appears to be a different hand; untitled and undated): Quantum dedecoris quantumque detrimenti ..., a letter sent by Frederick III to Charles VII, dated January 9th 1454 in other copies ${ }^{25}$.

As the last of these pieces seems to be a later addition, it is the first of them that provides the terminus post quem for the speeches of Cicero's: March 1452. Possibly the terminus ante quem for the whole manuscript is the death in 1458 of Íñigo López de Mendoza, Marquis of Santillana, presumed to have owned $\mathrm{it}^{26}$; but though some manuscripts were acquired for him in Italy by Nuño de Guzmán, 'une sorte d'agent du Marquis', Nuño's presence there is not attested after $1446^{27}$. On the other hand, the Marquis's second son, who became the first Conde de Tendilla, attended the Council of Mantua in 1459 and may already have been at the court of Pope Nicholas V in $1454^{28}$. However and whenever Madrid Nac. 10119 was acquired, if any of the other six manuscripts like it are earlier, it is not by much.

\section{Who Wrote MADRID NAC. 10119 AND WHERE?}

The scribe, Petrus de C. (f. 137r, at the end of Pridie), has not been identified, and no-one who signs his name in that way appears in the standard repertory ${ }^{29}$; but his hand does not look Italian, and in my experience the formula et sic est finis, which he uses in two subscriptions (f. 8r et sic est finis totius istius Pompeyane, f. $21 \mathrm{r}$ et sic est finis istis [sic] Miloniane divine orationis), is a mark of German scribes.

Nor has it been established where he wrote the manuscript. Albinia de la Mare tentatively assigned Bodl. Canon. Class. Lat. 255 to the scribe of Laur. Fies. 44, active in Florence round about $1460^{30}$, but Iacobus Pergulitanus, to whom she assigned Cesena $S$. 19.2, seems likely to have written it at Cesena about $1453^{31}$, and her verdict on Linc. Lat. 40 was

${ }^{25}$ L. Bertalot, Initia humanistica, no. 17749, who cites a handful of manuscripts but not this one.

${ }^{26} \mathrm{M}$. Schiff, La bibliothèque, 56-58.

${ }^{27} \mathrm{M}$. Schiff, La bibliothèque, lxxxvi, 449-59.

${ }^{28}$ M. Schiff, La bibliothèque, lxxxviii n. 2; but E. Meneses García, Correspondencia del Conde de Tendilla I (1508-1509), Madrid 1973, 14, suspects that the earlier attestation is a confused version of the later.

${ }^{29}$ Bénédictins du Bouveret, Colophons de manuscrits occidentaux des origines au XVI siècle V, Fribourg 1979, 68-79.

30 "New research on humanistic scribes in Florence", in A. Garzelli, Miniatura fiorentina del Rinascimento 1440-1525: un primo censimento, Indici e cataloghi toscani 18-19, 1985, I, 393-600, at 547. Xavier van Binnebeke kindly tells me that she later found a name for the scribe of Fies. 44: Michael Riccius.

31 "Lo scriptorium di Malatesto Novella", in F. Lollini \& P. Lucchi (ed.), Libraria domini. I manoscritti della Biblioteca Malatestiana: testi e decorazioni, Bologna 1995, 35-93, at 40, 72,74 no. 16. See also P. G. Pasini, Malatesta Novello magnifico signore: arte e cultura 
'probably Padua, s. $\mathrm{xv}^{2 / 4}$ (? 1440s)'32. The other three may also belong to north-eastern Italy. So too Vienna 3148, which has in the margin at the beginning of Pro Marcello (f. 8v) the note 'audita a Cristofero de Vincentinis a me Bonon. N.S. D. O.'. This N. S., whose initials frame the coat of arms on f. $1 r$, is identified by two entries on the verso of the flyleaf: 'Liber doctoris Nicolai Schult. canonici Wratislawiensis' and 'Reverendus pater dominus Johannes episcopus Wratislawiensis hunc librum cum multis aliis monasterio canonicorum regularium Sancte Dorothee Wienne ex relictis doctoris Nicolai Sculteti canonici et cantoris Wrat. ibidem sepulti assignari et illuc traduci curavit anno 1488'. Perhaps he acquired the manuscript at Bologna. Also relevant here is the Venice edition of 1471. If it did not include Poggio's German speeches but did include the Commentariolum, it would have the same content up to Pro Sestio, and in the same order, as Cesena S. 19.2, Palermo Naz. IV G 7, Parma Palat. 59, and Vat. Reg. Lat. 1486, but after Pro Archia it puts De lege agraria 3, after Pro Marcello, De lege agraria 1, and after Pro Sestio the rest of its German speeches in an order not attested so far as I know in any manuscript: De lege agraria 2, Pro Rabirio perduellionis reo, Pro Caecina, In Pisonem, Pro Rabirio Postumo. It ends with the spurious exchange of insults between Sallust and Cicero and then the Catilinarians. It is signed off with a poem in elegiacs about the printer (Christopher Valdarfer) and Cicero's oratory; the date M.CCCC.LXXI; and the name LODO. CARBO. Lodovico Carbone, a pupil of Guarino, taught at Ferrara from 1456 to his death in 1485 except for a year spent at Bologna, 1465-66 ${ }^{33}$. Presumably, besides composing the elegiacs, he prepared the speeches for publication. Nothing is known about his exemplar, but he surely acquired it in north-eastern Italy.

The first page of Madrid Nac. 10119 has a full though unelaborate border, and a decorated initial opens every speech of Cicero's and every piece at the end except the letter of 1454, confirmation that it was added later. Unhelpfully described as 'de tipo humanístico' ${ }^{34}$, the decoration may well be Spanish ${ }^{35}$.

di un principe del Rinascimento, Bologna 2002, 253-4 no. 261.

${ }^{32}$ S. Rizzo, Catalogo, 96. Similarly J. J. G. Alexander \& E. Temple, Illuminated manuscripts in Oxford college libraries, the University Archives and the Taylor Institution, Oxford 1985, 101 no. 973: Venice or Padua, s. $\mathrm{xv}^{2 / 4}$.

${ }_{33}$ Dizionario biografico degli italiani 19, 1976, 699-703 (L. Paoletti).

${ }^{34}$ J. Domínguez Bordona, Manuscritos con pinturas, Madrid 1933, I, 299 no. 731. Even less helpful is the description in Exposición de la biblioteca de los Mendoza del Infantado en el siglo XV, Madrid 1958, 37 no. 49: 'Capitales miniadas en cada oración'.

${ }^{35}$ For this opinion I thank Karl-Georg Pfändtner of the Bayerische Staatsbibliothek, with whom Stella Panayotova kindly put me in touch. Assuming that it was more likely to be Italian than anything else, I had sampled a dozen or so exhibition catalogues, manuscript catalogues, and volumes on Italian illumination, without finding anything closer than San Daniele Guarn. 37, probably written at San Daniele about 1449, for which see G. Mariani Canova, 


\section{The teXt OF THE FIRST THIRTEEN SPEECHES IN MADRID NAC. 10119}

Before taking leave of the manuscript, let me return to the first thirteen speeches, which it transmits almost entirely as it should. No manuscript that has all thirteen is earlier than the end of the 14th century. In my edition of Pro Quinctio I derived from Vat. Lat. 9305 all the others that have them in the same order ${ }^{36}$. Vat. Lat. 9305 itself has lost its final leaves after Post reditum ad Quirites 17 paene sensit, but descendants show that it must have run to the end of Post reditum in senatu. Three of the manuscripts concerned are French:

\section{Carpentras $358 \quad$ Paris B. N. Lat. $7780 \quad$ Paris B. N. Lat. 16226}

Paris Lat. 7780 is the only surviving manuscript that has just these thirteen speeches, but an Italian manuscript, Louvain Univ. 119, would be another if it had not perished in 1940, after the I. R. H. T. had photographed the beginning and end of every speech. The other Italian manuscripts concerned, besides Madrid Nac. 10119 and four relatives of it that I have been discussing, are these:

\author{
Holkham Hall 389 \\ Modena Est. Lat. 442 \\ Paris B. N. Lat. 7778 \\ Strängnäs F 7
}

Vat. Barb. Lat. 142

Vat. Ottob. Lat. 1510 (excerpts)

Vat. Pal. Lat. 1477

In my edition of Pro Quinctio I derived all the rest of these from B. N. Lat. 7778 because their texts of the two speeches Post reditum, which conflate in the same way the incomplete texts of Troyes Mun. $552\left(\mathrm{~s} . \mathrm{xiv}^{2 / 4}\right)$ and $B$. L. Harl. 4927, can be seen to have originated in it ${ }^{37}$.

\footnotetext{
"L'ornato rinascimentale nei codici guarneriani", in La Guarneriana. I tesori di un'antica biblioteca, San Daniele 1988, 35-46, at 35-6, 104 plate 9, and plate XXIX in L. Casarsa \& others, La libreria di Guarnerio d'Artagna, Udine 1991, and two manuscripts that Giovanni Marcanova says he commissioned at Padua, Venice Marc. Lat. IX 6 (3117) in 1440 and VI 160 (2816) in 1449, for which see S. Marcon, "La miniatura nei codici di Giovanni Marcanova", in La miniatura a Padova dal Medioevo al Settecento, Modena 1999, 481-93, at fig. 5-6. In connexion with Guarn. 37 Mariani Canova speaks of "manoscritti decorati "alla moderna", cioè ancora in chiave tardogotica', a manner that she describes as "un ornato fogliaceo ancora legato ai tradizionali moduli veneto-bolognesi in uso, sia a Venezia sia nel retroterra della Serenissima, nel secondo quarto del Quattrocento'; more precisely, 'tale tipo d'ornato, in uso ancora negli anni quaranta, scompare quasi completamente, o per lo meno perde il suo mordente, nella seconda metà del decennio successivo'. The likely date of Madrid Nac. 10119 and the character of its text seemed to fit, but I have no eye for decoration.

${ }^{36}$ M. D. Reeve, "Recovering annotations", $\mathrm{x}$-xvii.

${ }^{37}$ M. D. Reeve, "Recovering annotations", xiv. S. Rizzo, "Un codice veronese del Petrarca", L'Ellisse 1, 2006, 37-44, showed that Troyes 552 was probably written at Verona between
} 
Whether the same relationship holds throughout the thirteen speeches is a question of a kind that I have discussed elsewhere for its methodological interest ${ }^{38}$. No manuscript older than Petrarch, whose library made it possible to copy all thirteen, presented more than four of them as a block, and any account of the tradition that starts from older manuscripts will break them up into six elements:

\section{Pro lege Manilia, Pro Milone, Pro Plancio, Pro Sulla \\ Pro Archia \\ Pro Marcello, Pro Ligario, Pro rege Deiotaro \\ Pro Cluentio \\ Pro Quinctio, Pro Flacco \\ Post reditum ad Quirites, Post reditum in senatu}

Perhaps, therefore, the relationship between B. N. Lat. 7778 and the rest needs investigating in each element. Pro Milone may even have to be treated as a seventh element ${ }^{39}$.

Published evidence does not go far. Only in E. Olechowska's edition of Pro Plancio are the late as well as the early manuscripts assigned to different families ${ }^{40}$. Vat. Lat. 9305, which I regard as the source of her familia quarta and quinta, was one of the manuscripts that she did not use, but to her familia quarta she assigned the three French manuscripts and to her familia quinta not just B. N. Lat. 7778 and Madrid Nac. 10119, together with its relatives Linc. Lat. 40 and Vat. Reg. Lat. 1486, but also four other manuscripts that appear in my list: Louvain Univ. 119, Strängnäs F 7, Vat. Barb. Lat. 142, Vat. Pal. Lat. 1477. Few, however, of the readings by which she defines this family actually occur in $B$. N. Lat. 7778: just those shared with her familia quarta (but at 29 'pietas om.' should be 'est om.', and at 39 quidni and quid enim appear in the margin as

1335 and 1341 as a gift for Petrarch; see further M. Berté, "Petrarca”, 22-4.

38 "Dionysius the Periegete in miscellanies", in E. Crisci \& O. Pecere (ed.), Il codice miscellaneo: tipologie e funzioni $=$ Segno e Testo 2, 2004, 365-78, at 365-69. See also M. Zaccarello, Alcune questioni di metodo nella critica dei testi volgari, Verona 2012, 150-64. Over 80 short works attributed to Lucian are transmitted, and É. Marquis, "Les textes de Lucien à tradition simple", $R H T$ n. s. 8, 2013, 1-36, draws stemmatic conclusions from their order in various manuscripts.

${ }^{39}$ See R. H. Rouse \& M. D. Reeve in L. D. Reynolds (ed.), Texts and transmission, $82 \mathrm{n}$. 167, and M. Berté, "Petrarca”, 41-2.

${ }^{40}$ Fasc. 25 of the Teubner edition, Leipzig 1981, viii, xii. In her monograph 'Pro Cn. Plancio' et 'Pro C. Rabirio Postumo': la transmission des textes, Wrocaw 1984, she describes her manuscripts and gives more readings in some parts of the speech, but the monograph is hard to use, because she lists the manuscripts by country without providing an alphabetical table of her symbols. 
corrections for quin enim) and 80 nisi [qui], 81 [aut umquam fuerunt] ${ }^{41}$, 95 aliud for illud, 101 ali $<q u>o s$. Most of these, among them the last four, occur in Madrid Nac. 10119, and the last four are errors absent from Vat. Lat. 9305; against Vat. Lat. 9305 they also share 16 [eam] libertatem, et quam for perquam, 18 et alias et <etiam > in, 31 [pater ut in dimicatione fortunarum], 38 quae non for non quae, 48 tibi [ipsi], 58 illa tibi for ita tibi (Vat. Lat. 9305 has $i^{a}$ tibi), 62 si[n] minus, 64 floru[er]it, 69 tibi non for tibi tantum (Vat. Lat. 9305 has tibi tamen), 75 ipsum [id], 76 ut oppugnator for non oppugnator, 79 sed [etiam], 83 num vobis for non vobis, 84 non nimium for quod nimium, 85 [me id perdidisse], 98 via[m], 101 custodiam [etiam], meae noctis for tuae noctis. The Venice edition of 1471, the only relative of Madrid Nac. 10119 immediately accessible to me, has a few of the same readings: 16 [eam] libertatem, 18 et alias et <etiam> in, 38 quae non, 48 tibi [ipsi], 58 illa tibi, 62 si[n] minus, 76 ut oppugnator, 83 num, 101 custodiam [etiam], meae noctis. Besides errors, B. N. Lat. 7778 also has among its corrections some that must be conjectural, and those made between the lines rather than in the margin recur in Madrid Nac. 10119 and the edition, for instance 44 quod $<$ non $>$ eas, $54<a>$ Plancio. This sharing of both errors and conjectures makes descent from $B$. N. Lat. 7778 very likely, and it would be put beyond doubt if proof could be found that B. N. Lat. 7778 was copied directly from Vat. Lat. 9305, which would entail that any further errors shared with B. N. Lat. 7778 originated there. On the other hand, Madrid Nac. 10119 and the edition do not repeat the two most striking errors that Olechowska's familia quarta and B. N. Lat. 7778 inherited from Vat. Lat. 9305, namely 90 [mortem] and 103 licentiam for laetitiam. It follows that they cannot descend entirely from B. N. Lat. 7778. One of the other manuscripts that appear in my list, Modena Est. Lat. 442, is assigned by Olechowska to her familia nona, which she does not define but splits into four smaller classes; she puts it in IXd. As it has none of the errors that I have cited except 58 illa tibi (with ita tibi as a variant), it must again be contaminated if it descends from B. N. Lat. 7778 at all.

Collation of Pro lega Manilia 47-71 (the last third of the speech) yielded much the same result. Madrid Nac. 10119 shares with B. N. Lat. 7778 the following errors absent from Vat. Lat. 9305: 53 nobis erant $\sim, 56$ animus for annus, 59 una prope , 60 [inquit], 70 eos maxime , ab hoc for ex hoc. On the other hand, it does not share with Vat. Lat. 9305 and B. N. Lat. 777847 commemorasse for -are, 61 senatoris for -rio, 71 aliquam bonam gratiam [mihi]. Only the errors at 53 and 56 occur in Est. Lat. 442, though at 56 it has annus as a variant; but at 55 like B. N. Lat. 7778 it has in

${ }^{41}$ B. N. Lat. 7778 originally omitted aut umquam fuerunt quae ... possint, but quae ... possint was restored in the margin. 
the text putabat and as a variant the true reading pudebat, unambiguously transmitted in Vat. Lat. 9305.

On checking Madrid Nac. 10119 for the 28 innovations of B. N. Lat. 7778 that I listed in Pro Quinctio I find that it has all except 3 quod for quidem, 71 cum pio for cupio, and 89 et edicto for ex edicto ${ }^{42}$. I have also gone through my collation of $B$. N. Lat. 7778 again and found more innovations that Madrid Nac. 10119 shares: 30 [cum] Sex. Naevio (in a passage originally omitted by saut du même au même), 50 hominis for homine, 51 vi atque for vi ac, 53 ipse [qu]idem te consuluisti, 56 discat atque for discat ac, $82 \mathrm{tu}[\mathrm{m}]$ mittere, 89 quamplures for complures, 93 oportet for comportat. Descent from B. N. Lat. 7778 in Pro Quinctio too would therefore be certain if $B$. N. Lat. 7778 could be proved a direct copy of Vat. Lat. 9305, but the most I can say is that I found no reason why it should not be. The Venice edition of 1471, as might be expected from my account of it, agrees in almost all the passages that I have just cited with Madrid Nac. 10119 and even has 3 quod for quidem. In 1990-91 I checked the text of the speech in a large number of manuscripts, but I made only scrappy notes on those that I judged to be descripti or at least deteriores. I did, however, record a few errors that Modena Est. Lat. 442 and Vat. Pal. Lat. 1477 share with B. N. Lat. 7778. The speech has not survived in Vat. Barb. Lat. 142.

Except that enterprising work on the transmission of Pro Archia is in hand ${ }^{43}$, I have nothing to report about any of the other speeches. As I have mentioned in connexion with Pro Plancio and Pro Quinctio, it would help if evidence could be found that B. N. Lat. 7778 is or is not a direct copy of Vat. Lat. 9305.

${ }^{42}$ I must apologize for some mistakes in the list: at 42 defatigatur was not the original reading, the two passages of 62 are in the wrong order, in the second eiectum was not the original reading, at 63 the variant constitutus appears in the margin, at 79 in $<i>q u a m$ or $u n$ quam follows dic, not minime, and at 82 the reading could equally well be titum satis daret. At 63 Madrid Nac. 10119 has statutus vel constitutus in the text, and at 79 what ended up as inquam appears originally to have been iniquam or unquam.

${ }^{43}$ J. De Keyser, “The descendants of Petrarch's Pro Archia”, CQ n. s. 63, 2013, 292-328. 'In due time' he intends to test his stemmatic conclusions against the tradition of Pro Sulla. I thank him for giving me information about Modena Est. Lat. 442 and other manuscripts not discussed here. I am also grateful to Stephen Oakley and the two referees for helpful comments on an earlier draft. 
